\title{
Combined Operation of UPQC and Fuel Cell with Common DC Bus
}

\author{
.M.Ale-Emran ${ }^{1}$, M. Forghani ${ }^{2}$, M.Abedi ${ }^{1}$, G.B.Gharehpetian ${ }^{1}$ \\ 1-Electrical Engineering Department, Amirkabir University of Technology, Tehran, Iran \\ 2-Department of Electrical and Computer Engineering, Tehran, Iran \\ e-mails: aleemran2000@gmail.com,mehdiforghani2004@yahoo.com, abedi@aut.ac.ir,grptian@aut.ac.ir
}

\begin{abstract}
In this paper analysis results of a cooperation of the unified power quality conditioner with the fuel cell units are presented. A comprehensive control strategy is introduced to extract the compensating signals for the control of the proposed system. The used control strategy can extract the reference currents and voltages of UPQC fast and accurately in the presence of harmonics and/or frequency oscillation. The proposed scheme can compensate voltage sag, voltage interruption and harmonics at the Point of Common Coupling (PCC) on power distribution system. The simulation results prove the efficiency of using the presented method on power quality improvement.
\end{abstract}

\section{Key words}

Fuel Cell (FC), power quality, unified power-quality conditioner (UPQC)

\section{Introduction}

The increasing applications of electronic equipment that cause electromagnetic disturbances, or that are sensitive to these phenomena, has heightened the interest in power quality in recent years [1]. The quality of the power leads to a direct economic impact on utilities, their customers, and suppliers.

Custom power devices including power electronic interface can be the effective solution for increasing power quality problems because they can provide fast response and flexible compensation. Usually, series and shunt inverter integrated device is called Unified Power Quality Conditioner (UPQC). An effective control strategy is presented to extract the compensating signals for the control of the proposed system [2]-[6]. The UPQC has the prominent capability of improving the quality of voltage and current at the point of installation on power distribution systems or industrial power systems. Therefore, UPQC is expected to be one of the most powerful solutions to the load which is considered as very important or sensitive to supply voltage disturbances; however, cannot supply large active power to customers steadily due to the limitation of power storage [7]-[8].

While, the opening of the energy market under deregulation brings about the interest in Dispersed Generation (DG) because it can provide independence and flexibility to the customer in planning and developing the installation and can give economic benefits in many cases [9]. A fuel cell is a device that directly converts the chemical energy of fuel to electric energy. Recent advances in the fuel cell technology significantly improved the technical and economical characteristics of this technology. Environmental friendliness, practically noise free operation, and very high efficiency combined with the forecasted shift to gaseous fuels make fuel cells a very sound competitor on the future electricity markets [10]-[12].

However, FC can cause the negative effects on the existing power systems. That is, some potential problems might be occurred such as voltage variation, protection, harmonics, and personnel safety. The FC is interfaced in the AC and DC distributed system by using power electronic circuits. The DC voltage must be limited within an acceptable range during steady state and dynamic conditions by using suitable control strategies. This paper proposes a combined operation system of UPQC and fuel cell, which is connected to the dc link. The advantage of the proposed system over the UPQC is to compensate the voltage interruption, as well as the voltage sag, harmonics, unsymmetrical and unbalanced voltages.

The operation of the proposed system was verified through simulations with MATLAB/Simulink.

\section{Fuel Cell Model}

The fuel cell generation system which is considered in this study consists of a reformer and a stack that generates electricity using electrochemical reaction as shown in fig. 1 [13].

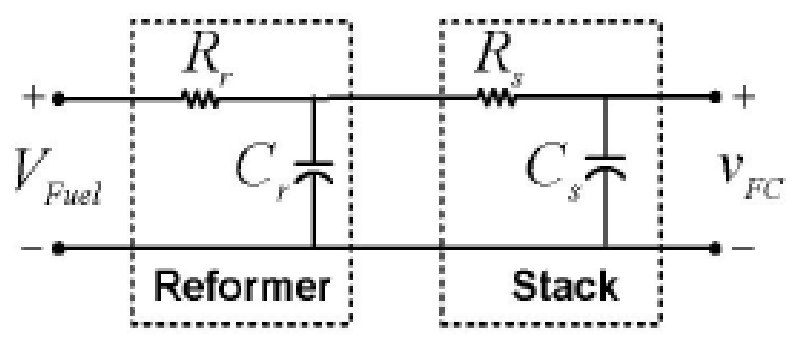

Fig. 1. Electrical model of the fuel cell system

The reformer produces usually hydrogen from fuels and then supplies it to the stacks. The stacks generate DC electric power by electrochemical reaction of hydrogen and oxygen which is in the air [14]-[15]. The reformer is represented as a first order time delay circuit which has relatively long time constant for an electrical equivalent circuit. The stack is a collection of unit cells and the unit cells consist of electrolyte, separators and plates. Fuel cell output is the result of a chemical reaction and possesses nonlinear characteristics. The stack is also represented as a first order time delay circuit which has a relatively short time constant.

Thus the mathematical model of the reformer and stack are represented as equation (1) and (2) respectively. 


$$
\begin{aligned}
& \frac{V_{c r}}{V_{i n}}=\frac{\frac{1}{C_{r} S}}{R_{r}+\frac{1}{C_{r} S}}=\frac{1}{1+R_{r} C_{r} S}=\frac{1}{1+\tau_{r} S} \\
& \frac{V_{c s}}{V_{c r}}=\frac{\frac{1}{C_{s} S}}{R_{s}+\frac{1}{C_{s} S}}=\frac{1}{1+R_{s} C_{s} S}=\frac{1}{1+\tau_{r} S}
\end{aligned}
$$

Where $\tau_{r}=R_{r} C_{r}$ is the time constant of the reformer, and $\tau_{s}=R_{s} C_{s}$ is the time constant of the stack. In general, $\tau_{r}$ is grater than $\tau_{s}$.

\section{Proposed System}

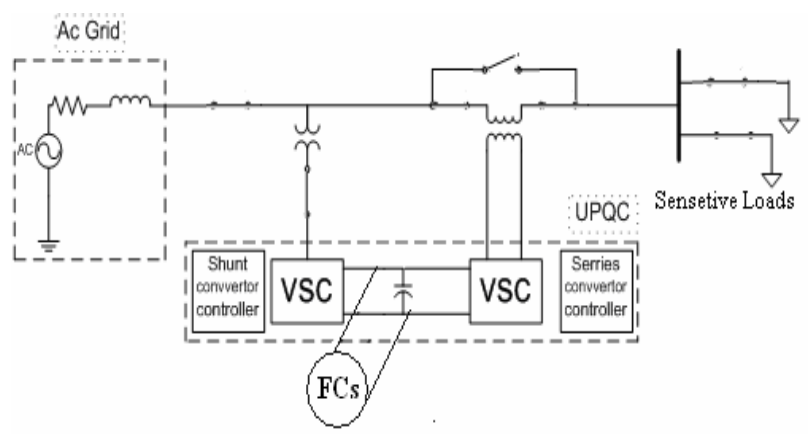

Fig.2: Combined operation of UPQC and FCs

Normally, UPQC has two voltage-source inverters in three-phase four-wire or three-phase three-wire configuration. One inverter called the series inverter is connected through transformers between the source and the common connection point. The other inverter called the shunt inverter is connected in parallel with the common connection point through transformers.

The series inverter operates as a voltage source, while the shunt inverter operates as a current source.

UPQC has compensation capabilities for the harmonic current, the reactive power compensation, the voltage disturbances, and the power-flow control. But UPQC has no capability in compensating the voltage interruption because there is no energy storage.

This paper proposes a new configuration of UPQC that has several FCs connected to the dc link as shown in Fig. 2. The UPQC can compensate the voltage interruption in the source, while the DG supplies power to the source and load or the load only.

\section{Control Scheme of the Proposed System}

The instantaneous power theory is used to control the proposed system. This scheme includes DG to deliver its power to loads and maintaining DC link voltage as well as other condition tasks. The theory is based on converting three axis parameters into two axes by defining well-known transfer matrix.

For example using the matrix for three phase voltage signals leads to $V_{\alpha}, V_{\beta}, V_{0}$. And finally, instantaneous active and reactive power, results from:

$$
\left[\begin{array}{c}
p_{0} \\
p \\
q
\end{array}\right]=\left[\begin{array}{ccc}
V_{0} & 0 & 0 \\
0 & V_{\alpha} & V_{\beta} \\
0 & -V_{\beta} & V_{\alpha}
\end{array}\right]\left[\begin{array}{l}
i_{0} \\
i_{\alpha} \\
i_{\beta}
\end{array}\right]
$$

Where $V_{\alpha}, V_{\beta}, V_{0}$ and $i_{\alpha}, i_{\beta}, i_{0}$ are the $\alpha-\beta-0$ transformation of $V_{a}, V_{b}, V_{c}$ and $i_{a}, i_{b}, i_{c}$ respectively. Then the active and reactive instantaneous power can be decomposed by DC component and AC harmonic components, which consist of negative sequence component and harmonic component [16]-[18].

$$
\left\{\begin{array}{c}
p=\bar{p}+\tilde{p} \\
q=\bar{q}+\tilde{q} \\
p_{0}=\bar{p}_{0}+\tilde{p}_{0}
\end{array}\right.
$$

Because the zero sequence power $p_{0}$ never produces a constant DC component without its associated AC component, the proposed system should compensate fully power $p_{0}$ when it is applied to a three-phase four-wire networks and the additional active power component drawn from supply needs to be injected:

$$
\left\{\begin{array}{c}
p_{\text {control }}=p_{0}+\tilde{p} \\
q_{\text {control }}=\bar{q}+\tilde{q}
\end{array}\right.
$$

Where:

$p_{0}$ is zero sequence of active power.

$\tilde{p}$ is negative sequence and AC harmonic component of active power.

$\bar{q}$ is direct component of reactive power.

$\tilde{q}_{\text {is alternative component of reactive power }}$ associated to the harmonic reactive component.

If shunt inverter is used simultaneously for reactive, negative and harmonic component compensation, the $\alpha-\beta$ axis current reference is given by the following equation:

$$
\begin{gathered}
{\left[\begin{array}{c}
i_{c \alpha}^{*} \\
i_{c \beta}^{*}
\end{array}\right]=\frac{1}{v_{\alpha}^{2}+v_{\beta}^{2}}\left[\begin{array}{cc}
v_{\alpha} & -v_{\beta} \\
v_{\beta} & v_{\alpha}
\end{array}\right]\left[\begin{array}{l}
-p_{\text {control }} \\
-q_{\text {control }}
\end{array}\right]} \\
{\left[\begin{array}{c}
i_{c a}^{*} \\
i_{c b}^{*} \\
i_{c c}^{*}
\end{array}\right]=[C]^{T}\left[\begin{array}{c}
i_{0} \\
i_{c \alpha}^{*} \\
i_{c \beta}^{*}
\end{array}\right]}
\end{gathered}
$$

Where 


$$
[C]^{T}=[C]^{-1}=\sqrt{2} / 3\left[\begin{array}{ccc}
1 / \sqrt{2} & 1 & 0 \\
1 / \sqrt{2} & -1 / 2 & \sqrt{3} / 2 \\
1 / \sqrt{2} & -1 / 2 & -\sqrt{3} / 2
\end{array}\right]
$$

When the series converter of the proposed configuration is used simultaneously for reactive, negative and harmonic compensation, the $\alpha-\beta$ axis voltage reference is given by equation (6).

$\left[\begin{array}{c}v_{c \alpha}^{*} \\ v_{c \beta}^{*}\end{array}\right]=\frac{1}{i_{\alpha}^{2}+i_{\beta}^{2}}\left[\begin{array}{cc}i_{\alpha} & -i_{\beta} \\ i_{\beta} & i_{\alpha}\end{array}\right]\left[\begin{array}{l}-p_{\text {control }} \\ -q_{\text {control }}\end{array}\right]$

$\left[\begin{array}{c}V_{c a}^{*} \\ V_{c b}^{*} \\ V_{c c}^{*}\end{array}\right]=[C]^{T}\left[\begin{array}{c}V_{0} \\ V_{c \alpha}^{*} \\ V_{c \beta}^{*}\end{array}\right]$

When the shunt converter of the proposed configuration is used for the charge control of battery, the active reactive power control is becoming the main issue, and the proposed system still satisfy the compensation demand of load such as negative and harmonic compensation. Then the $\alpha-\beta$ axis current reference is given by equation (8).

$\left[\begin{array}{l}i_{c \alpha}^{*} \\ i_{c \beta}^{*}\end{array}\right]=\frac{1}{v_{\alpha}^{2}+v_{\beta}^{2}}\left[\begin{array}{cc}v_{\alpha} & -v_{\beta} \\ v_{\beta} & v_{\alpha}\end{array}\right]\left[\begin{array}{c}p_{\text {control }}+p_{F C s} \\ q_{\text {control }}\end{array}\right]$

Where $p_{F C S}$ is the FCs power delivered to local loads by shunt converter. It should be noted that, it is so difficult to compensate reactive power and harmonic current using series converter only and because the signals from converter output terminals must be passed through the filters, the filter design strongly depends on the system parameters like load size and transformer turns ratio.

\section{Simulation Results}

\section{A. Compensation of voltage interruption}

Fig. 3 shows the simulation results when the source has a voltage interruption for $0.06 \mathrm{~s}$ from 0.06 to $0.12 \mathrm{~s}$. Fig. 3(a) and (b) shows the source voltage and the load voltage respectively. The load voltage maintains a constant value by the support of the shunt inverter voltage. Fig. 4 shows the DC voltage variation of the DC bus. During the voltage interruption, the shunt inverter only provides power to the load. The voltage of DC bus maintains a constant value by the support of FC units during the voltage interruption. Thus, it shows the stability and the reliability of the proposed system.

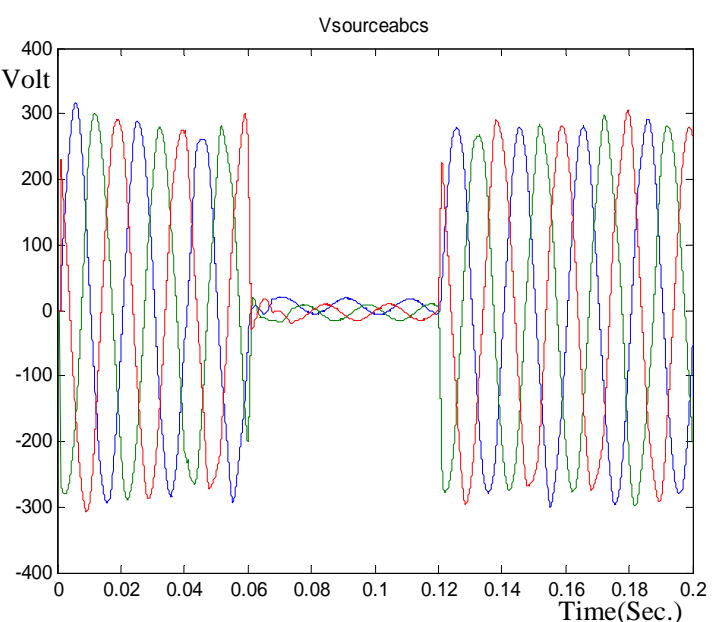

(a)

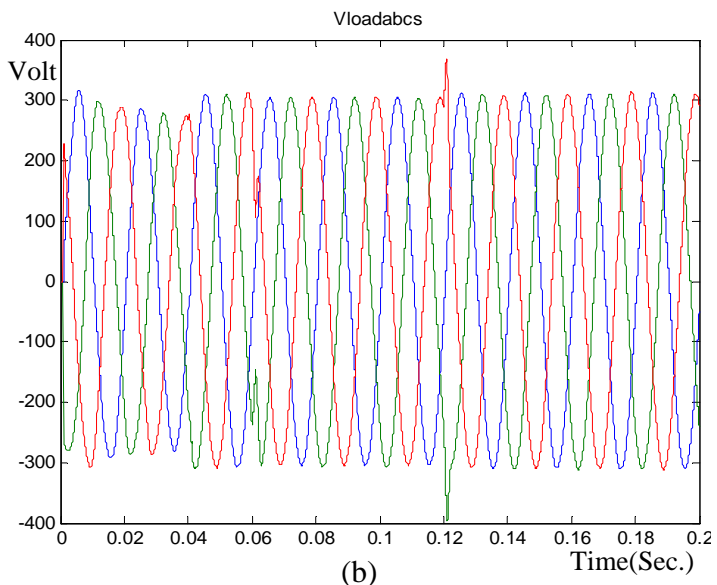

Fig.3: Voltage compensation under interruption. (a). Voltage Sources (b) Compensated voltage at PCC.

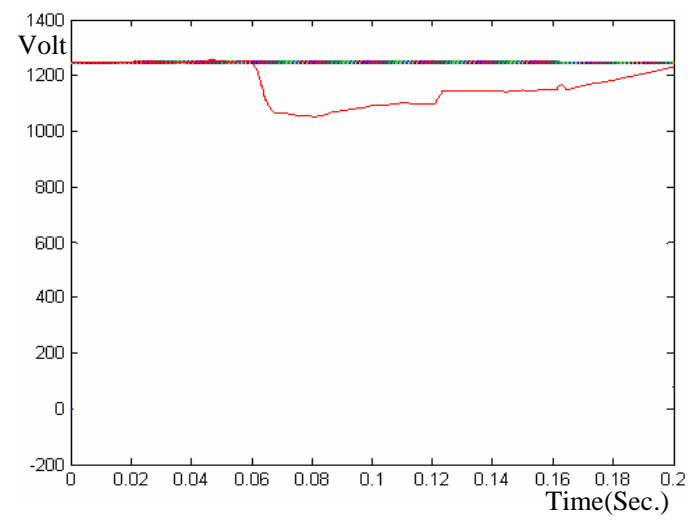

Fig. 4: DC link voltage oscillation under voltage interruption

\section{B. Compensation of current harmonics and unbalanced currents}

Figure 5 shows the effectiveness of the proposed system for compensation of current harmonics and unbalanced currents. It shows the simulation results when the shunt inverter of UPQC operates as an active power filter. Fig. 13(a)-(b) shows, respectively, the current waveform of the load and the source, in which the load current can be compensated by the shunt-inverter current to make the source current sinusoidal. 


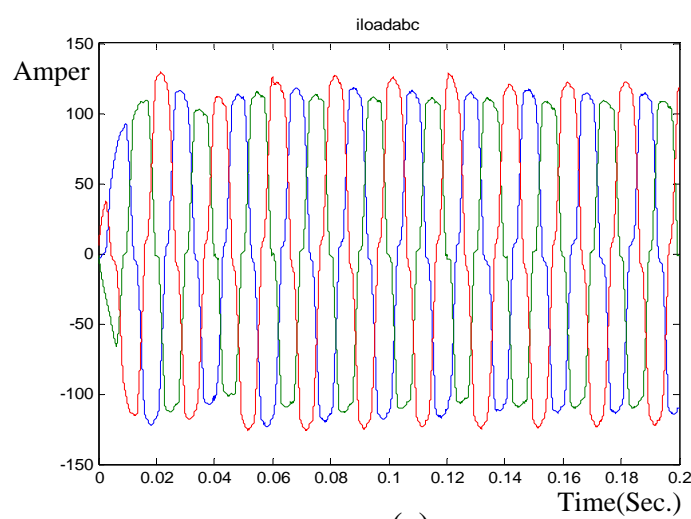

(a)

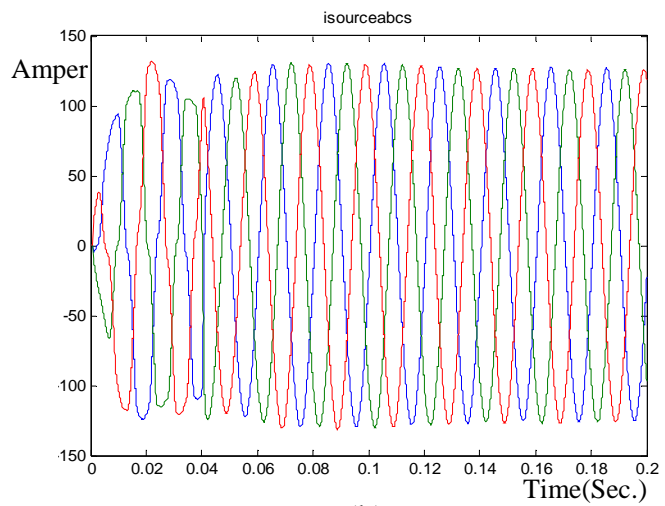

(b)

Fig5: Unbalanced current and current harmonic compensation. a) load currents b) compensated currents

\section{Compensation of voltage sag}

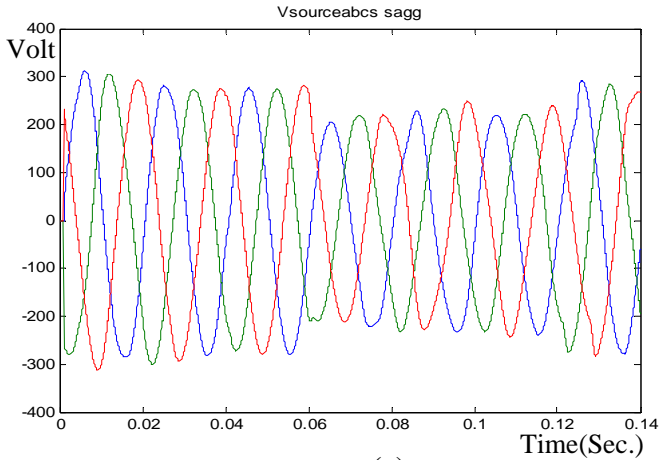

(a)

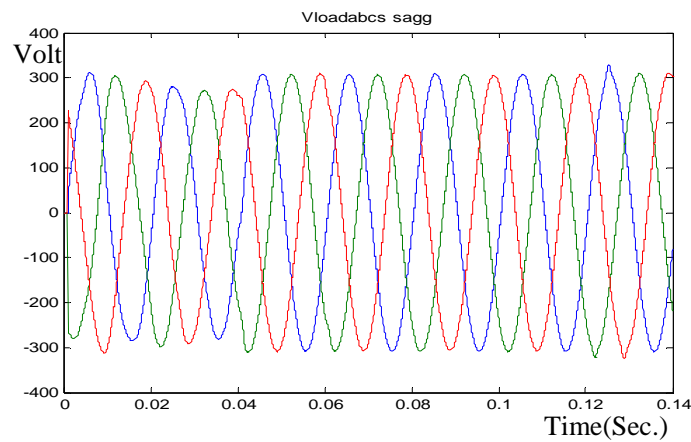

(b)

Fig. 6: Voltage sag compensation. a)source voltages b) load voltages

Fig. 6 shows the simulation results when the source has almost $30 \%$ of three-phase voltage sag. Fig. 6(a) and (b) shows the source voltage and the load voltage. The load voltage maintains a constant value as expected. During the sag interval, the reverse-flow source power is reduced and the series inverter covers this reduced amount to maintain the load power constant.

\section{Conclosion}

This paper describes the analysis results of a combined operation of the UPQC with the FC. The proposed system consists of a series inverter, a shunt inverter, and a Fuel Cell connected in the dc link. The proposed system can compensate voltage sag and swell, voltage interruption, reactive power, and harmonics, in its operation mode. The performance of the proposed system was analyzed using simulations with MATLAB/Simulink.

The proposed system can improve the power quality at the point of installation on power distribution systems or industrial power systems. The simulation model described in this paper can be utilized for the development of power systems.

\section{References}

[1] IEEE Std 1159 - IEEE Reconmended Pradce for monitoring Electric Power Quality. June 1995

[2] Mehdi Forghani Saeed Afsharnia, "Online Wavelet Transform-Based Control Strategy for UPQC Control System”, "Power Delivery, IEEE Transactions. Jan. 2007, vol.22, pp. 481-491

[3] K. Gokhale, A. Kawamura, and R. Hoft, "Deadbeat microprocessor control of PWM inverter for sinusoidal output waveform synthesis,"IEEE Trans. Ind. Appl., vol. IA-23, no. 5, pp. 901-910, Sep./Oct. 1987.

[4] A. A. Girgis and F. Ham, "A quantitative study of pitfall in FFT,” IEEE Trans. Electron. Syst., vol. ES-16, no. 4, pp. 434439, Jul. 1980.

[5] Aredes. M, K. Hemnn. and E.H. Watanabe. "An Universal Active Power Line Conditioner," IEEE Trans. on Power Delivery, vol.13, no.2. April 1998, pp545-551.

[6] H. Akagi. Y. Kanazawa, and A. Nabae. "Instantaneous Reactive Power Compensators Comprising Switching Devices without Energy Storage Components.” IEEE Trans. on Industry Application. vol. IA-20. no.3, May/June 1984, pp625-630.

[7] Han, B. Bae, B. Kim, H. Baek, S. "Combined operation of unified power-quality conditioner with distributed generation”."Power Delivery, IEEE Transactions” vol. 21, Jan. 2006, pp330- 338

[8] Sung-Woo Park Il-Yop Chung Joon-Ho Choi Seung-Il Moon Jae-Eon Kim, "Control schemes of the inverterinterfaced multi-functional dispersed generation. "Power Engineering Society General Meeting. vol.3, July 2003 pp19241929.

[9] Jms. G, B.T. Ooi. D. McGillis, F.D. Galiana and R. Marceau. "The Potential of Distributed Generation to Provide Ancillary Services,” PES SummerMeeting”. IEEE.2000. vol.3, pp1762-1767.

[10] R. Noroozian, M. Abedi, G. B. Gharehpetian and S. H. Hosseini, "On-grid and Off-grid Operation of Multi-Input Single-Output DC/DC Converter based Fuel Cell Generation System", ACEMP'07 and ELECTROMOTION'07 Joint meeting, Sep. 2007 Bodrum Turkey

[11] T.A. Nergaard, J.F. Ferrel, L.G. Leslie and J.S. Lai, "Design considerations for a $48 \mathrm{~V}$ Fuel Cell to Split single phase inverter system with ultra capacitor energy storage," in Proc. IEEE/PESC, Vol.4,Cairns, Australia June 23-27, 2002, pp.2007-2012

[12] J. Wang, F.Z. Peng, J. Anderson, A. Joseph and R. Buffenbarger, "Low cost fuel cell inverter system for residential power generation," in Proc IEEE/APEC,Vol.1,Anaheim, CA, Feb 22 - 26, 2004, pp. 367-37 
[13] Y. Kim, S. Kim, " An Electrical modeling and Fuzzy Logic Control of a Fuel Cell Generation System", IEEE Transactions on Energy Conversion, Vol. 14, No. 22, pp. 239-244, June 1999.

[14] J. Jung, M. Dai, A. Keyhani, "Modeling and Control of a Fuel Cell Based Z-Source Converter," IEEE Applied Power Electronics Conference and

Exposition, APEC'05, Vol. 2, pp. 1112-1118, March 6-10, 2005, Austin, TX

[15] Mahmoodi, M. Gharehpetian, G.B. Abedi, M. Noroozian, R ,"Novel and Simple Control Strategy for Fuel Cell Converters in DC Distribution Systems","Power and Energy Conference, PECon '06. IEEE International" Nov. 2006 pp. 358-362

[16] Salehi, V. Kahrobaee, S. Afsharnia, S.,’Power Flow Control and Power Quality Improvement of Wind Turbine Using Universal Custom Power Conditioner". "Industrial Electronics, July 2006 IEEE International Symposium”, vol. 3, pp.1888-1892

[17] Changjiang Zhan Ramachandaramurthy, V.K. Arulampalam, A. Fitzer, C. Barnes, M. Jenkins, N. ,"Universal custom power conditioner (UCPC) with integrated control" ," Power Engineering Society Winter Meeting, 2001. IEEE” vol.3, pp. 1039-1044 [18] Zhan Changjiang Wong Manchung Han Yu Han Yingduo Zhao Liangbing ,"Universal custom power conditioner (UCPC) in distribution networks”, “ Power Electronics and Drive Systems, 1999. PEDS '99. Proceedings of the IEEE 1999 International Conference”, vol. 2, pp.1067-1072 